\title{
TINJAUAN KEADAAN SANITASI PASAR UMUM \\ BLAHBATUH DI KECAMATAN BLAHBATUH KABUPATEN GIANYAR TAHUN 2021
}

\author{
Ni Putu Vinka Seviana ${ }^{1}$, Nengah Notes ${ }^{2}$, I Ketut Aryana ${ }^{3}$
}

\begin{abstract}
Sanitation of public places is an effort to monitor and prevent losses as a result of unkempt public places that result in the transmission of various types of diseases, environmental pollution and health disorders. Public facilities are one of them market. Dirty and rundown markets can be a place of vector breeding and a place of spread of infectious diseases for buyers and sellers, therefore there needs to be sanitary supervision in the market. The purpose of this study is to find out the sanitation situation of Blahbatuh Public Market in Blahbatuh Subdistrict, Gianyar Regency 2021. The type of research used descriptively is to review the sanitation of Blahbatuh Public Market including buildings, sanitation facilities and market security by using observation sheets. The results of the research on the sanitary condition of Blahbatuh Public Market obtained include buildings with a score of 14 categories. Sanitation facilities with a score of 18 categories are sufficient. Market security with a score of 5 categories is enough. In general, the sanitary condition of Blahbatuh Public Market scored 37 with enough categories. Researchers recommend treating and equipping market means. To traders and visitors to jointly maintain market facilities and market cleanliness.
\end{abstract}

Keywords: Situation, Sanitation, Market

\section{PENDAHULUAN}

Secara global, permasalahan sanitasi menjadi masalah di seluruh dunia. Buruknya akses terhadap sarana sanitasi berkaitan erat dengan penularan berbagai macam penyakit menular. ${ }^{1}$. Sanitasi memegang peranan yang penting dalam pembangunan kesehatan, salah satunya lingkungan tempat-tempat umum. Sanitasi pada tempat-tempat umum merupakan bagian dari upaya yang harus dilakukan dalam peningkatan derajat kesehatan masyarakat. $^{2}$
Pasar termasuk tempat umum yang merupakan sarana dimana orang banyak berkumpul dan mengadakan interkasi. ${ }^{3}$. Pasar yang kotor dan kumuh dapat menjadi tempat perkembangbiakan vektor serta tempat bersebarnya penyakit menular untuk para pembeli maupun penjual. ${ }^{4}$. Selain itu pasar memiliki posisi yang sangat penting dalam menyediakan pangan yang aman, sehingga harus memenuhi kriteria pasar sehat, yaitu kondisi pasar yang bersih, nyaman, aman dan sehat. ${ }^{5}$ 
Berdasarkan hasil survei pendahuluan di lapangan, dari 20 pengunjung di wawancarai, $38 \%$ yang menyatakan bahwa kondisi bangunan terawat dan bersih, sementara $62 \%$ menyatakan kondisi bangunan tidak terawat dan masih kotor. Hal tersebut karena tidak adanya partisipasi baik dari pedagang maupun pengunjung dalam menjaga kebersihan pasar. Di samping itu sebanyak 20 pedagang los dari 187 pedagang diantaranya $30 \%$ mempunyai tempat sampah basah dan kering sedangkan $70 \%$ tidak mempunyai tempat sampah basah dan kering sehingga pedagang membuang sampah sembarangan ke selokan yang terbuka yang bisa menimbulkan bau tidak sedap dan bisa menjadi tempat berkembangbiaknya vektor penyakit.

\section{METODE PENELITIAN}

Jenis penelitian yang digunakan dalam penelitian ini adalah deskriptif. Penelitian deskriptif merupakan suatu metode penelitian yang dilakukan dengan tujuan untuk mengetahui gambaran atau deskripsi tentang suatu masalah kesehatan, baik yang berupa faktor risiko maupun faktor efek. ${ }^{6}$

Penelitian ini dilakukan dengan observasi keadaan sanitasi pasar meliputi bangunan, sarana sanitasi dan keamanan pasar dengan menggunakan formulir checklist yang mengacu pada Keputusan Menteri Kesehatan Republik Indonesia Nomor 519/MENKES/SK/VI/2008 Tentang Pedoman Penyelenggaraan Pasar Sehat yang telah di modifikasi. Penelitian dilakukan di Pasar Umum Blahbatuh dilaksanakan pada bulan Januari sampai dengan April 2021.

\section{HASIL DAN PEMBAHASAN}

Adapun hasil pengamatan penilaian keadaan sanitasi meliputi bangunan, sarana sanitasi dan keamanan di Pasar Umum Blahbatuh yang dapat dilihat pada tabel 1 sebagai berikut : 
Tabel 1

Hasil pengamatan keadaan sanitasi Pasar Umum Blahbatuh Tahun 2021

\begin{tabular}{clcc}
\hline No & \multicolumn{1}{c}{ Item Penilaian } & Skor & Kategori \\
\hline 1 & Bangunan & 14 & Cukup \\
2 & Sarana sanitasi & 18 & Cukup \\
3 & Keamanan & 5 & Cukup \\
\hline \multicolumn{2}{r}{ Total } & 37 & Cukup \\
\hline
\end{tabular}

\section{A. Bangunan}

1. Bangunan pasar

Keadaan bangunan kurang terpelihara seperti fasilitas tidak terawat baik dan bersih, terdapat lantai yang retak, tidak rata, licin dan sulit dibersihkan. Pada atap bangunan pasar terdapat atap yang berlubang yang memungkinkan menjadi tempat perindukan vektor penyakit, sarang serangga dan debu pada langit-langit pasar, dinding tidak bersih, lembab dan kotor. Lorong pasar digunakan sebagai tempat berjualan dan peralatan atau bahan dagangan diletakkan tidak pada tempatnya sehingga menghalangi badan jalan.

2. Bangunan los

Bangunan los kurang terawat kebersihannya dan keadaan bangunan yang sudah tua mengakibatkan bangunan los rusak. Terdapat sampah yang berserakan menumpuk di depan los dan sampah dibuang pada selokan depan los. Penelitian ini sejalan dengan penelitian yang dilakukan Ginting (2017) yaitu Beberapa pedagang menumpuk sampah mereka di depan atau di samping kios/los sehingga menimbulkan bau tidak sedap serta mengganggu kenyamanan para pengunjung selain itu, tumpukan sampah dapat menjadi tempat perkembangbiakan lalat, nyamuk, dan kecoa. ${ }^{7}$

3. Tempat Penjualan Makanan dan

$$
\begin{aligned}
& \text { Bahan Pangan } \\
& \text { Penyajian dagangan }
\end{aligned}
$$

dikelompokan tidak sesuai jenisnya serta pedagang makanan siap saji belum pernah dilakukan usap dubur oleh petugas kesehatan. Tempat dan alas pemotong makanan dan bahan makanan sebagian besar terbuat dari kayu. Meja tempat berjualan seharusnya tidak terbuat dari kayu untuk menghindari pertumbuhan kuman serta memudahkan dalam pembersihannya. Alas pemotong berbahan kayu dan pisau tidak anti karat sumber pencemaran bagi karkas karena pisau dan talenan ini 
tidak mudah dibersihkan sehingga dapat menjadi tempat bakteri berkembangbiak. $^{8}$

\section{Area Parkir}

Terdapat tempat parkir untuk sesuai jenis kendaraan, tempat parkir kendaraan pengangkut unggas hidup terpisah, terdapat jalan khusus yang tembus ke belakang pasar yang digunakan untuk tempat keluar masuknya unggas hidup. Terdapat jalur masuk dan keluar terpisah dengan jelas serta adanya tanaman penghijauan.

5. Pencahayaan, suhu dan kelembaban

Hasil pengukuran pencahayaan di setiap Los Pasar Umum Blahbatuh didapatkan hasil yaitu rata-rata 304,3 lux dari pengukuran pencahayaan tiap los. Hasil pengukuran suhu didapatkan rata-rata suhu yaitu $31^{\circ} \mathrm{C}$ hal ini menunjukan bahwa los pasar panas dan pengap untuk melakukan aktivitas atau kegiatan. Hasil pengukuran kelembaban didapatkan rata-rata kelembaban $47,2 \%$. Pencahayaan merupakan salah satu faktor untuk mendapatkan keadaan lingkungan yang aman serta nyaman dan berkaitan erat dengan produktivitas manusia. ${ }^{9}$. Suhu dan kelembaban sangat erat hubungannya karena kelembaban relatif udara berubah berbanding terbalik dengan perubahan suhu udara, yaitu bila udara dingin maka kelembaban meningkat dan bila udara panas maka kelembaban menurun. ${ }^{10}$

\section{B. Sarana Sanitasi}

1. Air bersih

Air bersih mengalir dengan jumlah yang cukup, mudah dijangkau, berfungsi dengan baik, dan kualitas fisik air memenuhi persyaratan. Jarak sumber air dengan septick tank sejauh 10 meter. Penelitian ini sejalan dengan penelitian yang dilakukan Yunanda (2015) yaitu air sudah tersedia dengan jumlah yang cukup, air yang di gunakan bersumber dari PDAM dan sudah memenuhi syarat kualitas air secara fisik tidak bewarna, tidak berbau dan tidak berasa. ${ }^{11}$

2. Kamar mandi dan toilet

Kamar mandi dan toilet di Pasar Umum Blahbatuh yaitu lantai kamar mandi sulit dibersihkan, terdapat lantai yang retak serta terdapat genangan air dan kondisi lantai yang licin. Toilet laki-laki dan perempuan tidak terpisah, pencahayaan mendapatkan hasil kurang dari 50 
lux. Letak kamar mandi 3 meter dengan tempat penjualan makanan dan bahan pangan. Keadaan seperti ini dapat menyebabkan kontaminasi bahan pangan oleh bakteri penyebab penyakit yang berasal dari kamar mandi dan toilet. ${ }^{12}$

\section{Pengelolaan sampah}

Tempat sampah yang digunakan berupa keranjang dan karung, tidak semua pedagang memiliki tempat sampah yang terbuat dari bahan yang kuat, kedap air dan tertutup. Sampah tidak dipilah, terdapat TPS (Tempat Penampungan Sementara) hanya saja tempat penampungan sementara berada pada jalur utama pasar (sebelah barat dekat dengan pintu keluar) berjarak kurang dari 1 meter dari bangunan pasar.

4. Saluran limbah/drainase

Selokan atau saluran limbah terdapat tutup dengan kisi-kisi logam namun sudah jebol dan rusak sehingga terdapat sampah menumpuk dan tersumpat, aliran limbah tidak lancar, belum pernah ada pengujian kualitas limbah cair secara berkala setiap 6 bulan sekali.

5. Tempat cuci tangan

Tempat cuci tangan dilengkapi dengan sabun serta tersedia tempat cuci tangan dengan air mengalir dengan jumlah yang cukup. Tempat cuci tangan mudah dijangkau dengan jumlah yang cukup dikarenakan pandemi covid-19 yang meningkat, hal ini bertujuan untuk melakukan pencegahan penularan covid-19.

6. Pengendalian binatang penular penyakit

Terdapat tikus dan ditemukan kecoa pada tempat penjualan sesajen. Selain itu terdapat anjing liar dan kucing yang berkeliaran di sekitar pasar. Dalam pengendalian vektor tidaklah mungkin dapat dilakukan pemberantasan sampai tuntas, yang mungkin dapat dilakukan adalah usaha mengurangi dan menurunkan populasi kesatu tingkat yang tidak membahayakan kehidupan manusia. $^{13}$

\section{Keamanan}

1. Pemadam kebakaran

Tersedia alat pemadam kebakaran dengan jumlah yang cukup dan berfungsi namun tidak terdapat SOP (Standard Operating Procedure) serta pasar belum tersedia hidran air sehingga pemadam kebakaran akan kesulitan untuk mencari sumber air yang digunakan untuk memadamkan api. 
2. Petunjuk keamanan

Tidak terdapat titik kumpul dan jalur evakuasi. Pencegahan Kecelakaan dapat diterapkan dengan menjamin pengunjung atau pengguna atau konsumen dari kejadian kecelakaan akibat menggunakan fasilitas tempat-tempat umum seperti tersedia pintu darurat yang berfungsi baik dan tersedia peringatanperingatan tertulis yang mudah dibaca. $^{14}$

\section{Pos keamanan}

Terdapat pos keamanan dan petugas keamanan dengan jumlah yang cukup untuk membantu menjaga keamanan dan kenyaman pembeli dan pengunjung pasar.

\section{SIMPULAN}

Berdasarkan hasil penelitian dan pembahasan yang telah disampaikan, maka dapat disimpulkan bahwa keadaan bangunan, sarana sanitasi dan keamanan di Pasar Umum Blahbatuh di kategorikan cukup.

\section{SARAN}

Adapun saran yang dapat diberikan oleh peneliti yaitu bagi pengelola disarankan menjaga dan merawat fasiltas pasar seperti memperbaiki sarana pasar yang rusak serta menjamin kesehatan pedagang, bagi pedagang dan pengunjung disarankan untuk menjaga kebersihan lingkungan pasar agar merasa nyaman saat melakukan aktivitas jual beli dan terhindar dari berbagai resiko penularan penyakit.

\section{DAFTAR PUSTAKA}

1. Marinda, D. \& Ardillah, Y. Implementasi Penerapan Sanitasi Tempat-tempat Umum Pada Rekreasi Benteng Kuto Besak Kota Palembang. J. Kesehat. Lingkung. Indones. 18, 89 (2019).

2. Suryadi, I., Seviana, R. \& Siti, R. Penerapan Hygiene Dan Sanitasi Hotel Kusuma Kartika Sari Di Kota Surakarta. 2, 141-151 (2018).

3. Efendi, R. \& Syifa, J. N. A. Status Kesehatan Pasar Ditinjau dari Aspek Sanitasi dan Perilaku Hidup Bersih Sehat (PHBS) pada Pasar Ciputat dan Pasar Modern BSD Kota Tangerang Selatan. Kesehat. Indones. IX, 122-128 (2019). 
4. Hamdani, Farman \& Inna, N. Analisis Penyelenggaraan Pasar Sehat TAC Kota Jambi Tahun 2019. Sci. J. 8, 175-190 (2019).

5. KEPMENKES RI. Keputusan Menteri Kesehatan RI No. 519/MENKES/SK/VI/2008, tentang Pedoman Penyelenggaraan Pasar Sehat. (2008).

6. Riyanto, A. Aplikasi Metodologi Penelitian Kesehatan. (Nuha Medika, 2011).

7. Ginting, D. S. B. Tinjauan Sanitasi Pasar Kota Kabanjahe Kabupaten Karo Tahun 2017. (Politeknik Kesehatan Medan, 2017).

8. Rafika, N. Tingkat Cemaran Bakteri Escherischia coli Pada Daging Ayam Yang Dijual Di Pasar Tradisional Makassar. Pros. Semin. Nas. Megabiodiversitas Indones. Univ. Alauddin Makasar 42-50 (2018).

9. Pangestika, P. R. Pencahayaan Merupakan Salah Satu Faktor Untuk Mendapatkan Keadaan Lingkungan Yang Aman dan Nyaman dan Berkaitan EratDenganProduktivitasManusi a.https://www.academia.edu/405 6883/Pencahayaan_merupakan_s alah_satu_faktor_untuk_mendap atkan_keadaan_lingkungan_yang _aman_dan_nyaman_dan_berkait an_erat_dengan_produktivitas_m anusia (2010).

10. Sandi, I., Ariyasa, I., Teresna, I. \& Ashadi, K. Pengaruh Kelembaban Relatif Terhadap Perubahan Suhu Tubuh Latihan. Sport Fit. J. 5, 103-109 (2017).

11. Yunanda, F., Selviana \& Pradana, T. D. Gambaran Kondisi Sanitasi Pasar Tradisional Di Kota Pontianak Tahun 2015. Fak. Ilmu Kesehat. (2015).

12. Nurcahaya, K., Moelyaningrum, A. D. \& Ningrum, P. T. Identifikasi Sanitasi Pasar di Kabupaten Jember (Studi di Pasar Tanjung Jember). e-Jurnal Pustaka Kesehat. 2, 285-292 (2014).

13. Ratih, D. A. Tingkat Kesehatan Pasar Tradisional Desa Adat Guwang Kecamatan Sukawati Kabupaten Gianyar Tahun 2016. (Politeknik Kesehatan Denpasar, 2016). 
14. Suyono \& Budiman. Ilmu

Kesehatan Masyarakat Dalam

Konteks Kesehatan Lingkungan.

(Penerbit Buku Kedokteran.EGC,

2010). 